Handep Jurnal Sejarah dan Budaya

Vol. 3, No. 1, Desember 2019, hlm. 101-120

\title{
BUDAYA KEMPONAN \\ PADA MASYARAKAT MELAYU PONTIANAK \\ (KAJIAN KEARIFAN LOKAL \\ DALAM KEHIDUPAN SOSIAL ETNIK MELAYU)
}

\author{
THE CULTURE OF KEMPONAN \\ IN PONTIANAK MALAY SOCIETY \\ (A STUDY OF LOCAL WISDOM \\ ON THE SOCIAL LIFE OF MALAY ETHNIC)
}

\author{
Muhammad Asyura \\ Universitas Pendidikan Indonesia \\ Jln. Setia Budi No.229 Bandung, Indonesia \\ muhammadasyuramuhammad@gmail.com
}

Diterima tanggal 10 Januari 2019

Disetujui tanggal 14 Agustus 2019

\begin{abstract}
Kemponan is an embodiment of Pontianak Malay local culture which teaches social values in the form of suggestion. Kemponan is regarded as the culture which acknowledges and appreciates someone's offer or gift especially food and beverage. This research was qualitative research with in-depth interview technique. The purpose of this research was to describe kemponan according to the reason, its media, prevention pattern and social culture value within it. This research has shown that kemponan happened because of negative suggestion in someone who believes that harm or accident may happen if he/she does not eat or drink what has been offered by the host. Media of kemponan is food and beverage, even sacred refreshment of Pontianak Malay. As a negative suggestion, some certain actions can break kemponan, either by touching the refreshment or saying the words 'cempalet' and 'palet' which contain social values to prevent unexpected harm if someone refuses the offer of sacred refreshment. The local wisdom of kemponan in touching the offer or saying 'cempalet' 'palet' are 1) the cultural value which appreciates fellow human beings; 2) the cultural value which appreciates the nature; and 3) the religious and cultural value.
\end{abstract}

Keywords: kemponan, local wisdom, and Pontianak Malay.

\begin{abstract}
ABSTRAK
Kemponan merupakan perwujudan kebudayaan lokal masyarakat Melayu Pontianak yang mengajarkan nilai sosial dalam bentuk sugesti. Kemponan merupakan budaya menghargai dan mengapresiasi sebuah tawaran ataupun pemberian orang lain berupa makanan dan minuman. Penelitian ini dilakukan dengan metode kualitatif dengan teknik wawancara mendalam. Penelitian ini bertujuan untuk mendeskripsikan budaya kemponan berdasarkan sebab dan media terjadinya, pola pencegahannya, dan nilai sosial budaya yang terkandung
\end{abstract}


di dalamnya. Penelitian ini menunjukkan bahwa sebab terjadinya budaya kemponan ialah adanya sugesti negatif dalam diri seseorang mana kala tidak memakan atau meminum yang disuguhkan atau yang diinginkan sehingga akan menimbulkan bala atau celaka bagi orang tersebut. Media terjadinya kemponan ialah makanan dan minuman, bahkan terdapat beberapa makanan dan minuman yang disakralkan oleh masyarakat Melayu Pontianak. Sebagai sebuah 'sugesti negatif' kemponan dapat dicegah dengan cara 'dipatahkan' melalui perilaku khas yang disebut jamah, cempalet, dan palet; yang mengandung nilai-nilai sosial yang berfungsi sebagai penangkal bala atau celaka mana kala seseorang menolak ajakan untuk menyantap makanan ataupun minuman tertentu yang dianggap sakral. Di dalam perilaku menjamah, cempalet dan palet, budaya kemponan mengandung nilai kearifan lokal yaitu 1) nilai budaya saling menghargai sesama manusia, 2) nilai budaya menghargai alam, dan 3) nilai budaya religi.

Kata kunci: kemponan, kearifan lokal, dan Melayu Pontianak.

\section{A. PENDAHULUAN}

Kebudayaan adalah cara hidup yang dianut secara kolektif dalam suatu masyarakat (Sumarto dalam Mardimin, 1994: 55). Kebudayaan tercipta karena keberadaan manusia. Manusialah yang menciptakan kebudayaan dan manusia pula yang menjadi pemakainya sehingga kebudayaan akan selalu ada sepanjang peradaban manusia. Kebudayaan dari sudut pandang antropologi dianggap sebagai tata kehidupan, way of life, dan tata tingkah laku (Pelly, 1994: 5). Kebudayaan dan masyarakat merupakan dua hal yang tidak bisa dipisahkan.

Dalam perkembangannya, budaya masyarakat menghasilkan corak-corak khas yang tercermin dalam budaya etnikal. Satu daerah yang memiliki kekayaaan budaya etnikal adalah Kalimantan Barat (selanjutnya ditulis Kalbar). Kalbar memiliki tingkat keragaman budaya yang tinggi. Kalimantan Barat merupakan provinsi yang unik dalam kajian etnik dan kebudayaan.
Selain memiliki kekayaan budaya etnikal, Kalbar juga diperkaya dengan letak geografis. Kalbar merupakan daerah destinasi yang strategis yang merupakan teras terdepan Indonesia. Kalbar berbatasan langsung dengan Malaysia dan Brunei Darussalam.

Keunikan budaya di Kalbar juga muncul dari polarisasi identitas pelaku kebudayaan atau etnik masyarakatnya. Satu di antara identitas etnik 'asli' Kalbar yaitu etnis Melayu yang memiliki khazanah kebudayaan yang menarik.

Melayu sebagai sebuah identitas pelaku kebudayaan Kalbar terbagi menjadi lima wilayah kebudayaan besar. Satu di antara kebudayaan itu adalah kebudayaan Melayu Pontianak dengan wilayah domisili di Kota Pontianak dan Kabupaten Pontianak (Effendi, 2006: 85). Wilayah kebudayaan ini memiliki khazanah kebudayaan lokal yang unik. Satu di antara kebudayaan Melayu yang unik dan menarik untuk diteliti ialah budaya kemponan. 
Kemponan merupakan perwujudan kebudayaan lokal masyarakat Melayu Pontianak yang mengajarkan nilai sosial. Hal ini diperkuat dengan teori bahwa kebudayaan juga dianggap sebagai sebuah sistem sosial (Koentjaraningrat dalam Pelly, 1994: 33) yang akan memberi gambaran tentang aktivitas manusia dalam berinteraksi dan bertingkah laku dengan pola-pola tertentu sesuai adatkelakuan. Hal tersebut juga dikuatkan oleh Anwar (1995: 12) bahwa sistem sosiokultural amat erat kaitannya untuk menganalisis semua komponen termasuk bahasa, tingkah laku, dan pola pikir masyarakat.

Di era modern saat ini, penghayatan terhadap tradisi kemponan mulai merosot khususnya di kalangan anak muda. Hal ini menggambarkan bahwa budaya dan tradisi kemponan pada etnik Melayu Pontianak mulai ditinggalkan. Minimnya pengetahuan dan pewarisan budaya pada generasi muda membuat mereka tidak paham akan tradisi kemponan. Generasi muda belum memahami sisi positif dari budaya kemponan sebagai sebuah apresiasi terhadap pemberian orang lain. Hal ini semakin membuat generasi muda cenderung untuk hidup dalam kegiatan yang konsumtif dan mubazir.

Kemponan merupakan sebuah sugesti yang menyebabkan masyarakat Melayu memiliki perilaku atau sikap sosial. Sikap sosial ini memiliki nilainilai yang arif, seperti menghargai hubungan sosial antara sesama manusia, alam, dan Tuhan. Sehingga budaya kemponan pada masyarakat Melayu menjadi budaya yang sarat dengan nilai-nilai yang sakral. Karena itu, budaya kemponan sangat menarik untuk diteliti sebagai kajian kebudayaan.

Masalah dalam penelitian ini adalah bagaimana perilaku kemponan berdasarkan sebab dan media terjadinya, pola pencegahan, dan nilai budaya yang terkandung di dalamnya? Dengan demikian, tujuan penelitian ini tentunya untuk mendeskripsikan sebab dan media terjadinya, pola pencegahan, dan nilai budaya yang terkandung dalam budaya kemponan pada masyarakat Melayu Pontianak.

\section{B. METODE}

Penelitian ini merupakan penelitian kualitatif dengan teknik observasi dan wawancara mendalam. Penelitian kualitatif merupakan penelitian bertujuan yang mendeskripsikan secara utuh suatu gejala. Pendeskripsian tersebut dapat bersumber dari naskah wawancara, catatan lapangan, dokumen pribadi, catatan, memo, dan dokumen resmi lainnya.Tujuan dari penelitian kualitatif ini adalah menggambarkan realita empirik di balik fenomena secara mendalam, rinci, dan tuntas. Oleh karena itu, penggunaan pendekatan kualitatif dalam penelitian ini adalah dengan mencocokkan antara realita empirik dengan teori yang berlaku (Moleong, 2004: 131).

Pendekatan atau kajian yang digunakan dalam penelitian adalah kajian antropologi. Antropologi adalah 
salah satu cabang ilmu pengetahuan sosial yang mempelajari tentang budaya masyarakat suatu etnis tertentu. Antropologi lebih memusatkan pada penduduk yang merupakan masyarakat tunggal (tinggal di daerah yang sama). Hal ini sejalan dengan pendapat Koentjaraningrat (1986: 8) bahwa antropologi adalah ilmu yang mempelajari umat manusia pada umumnya, dengan mempelajari bentuk fisik masyarakat serta kebudayaan yang dihasilkan.

Berdasarkan kebutuhan dalam masalah penelitian, dipilihlah kajian antropologi budaya. Antropologi budaya, dibedakan lagi menjadi lima yaitu etnoliguistik (bahasa dalam kebudayaan), prehistori (sejarah aksara), antropologi spesifikasi (pengembangan antropologi murni), antropologi terapan, dan etnologi (Koentjaraningrat, 1986: 23). Penelitian ini akan berfokus pada kajian etnologi yaitu mendeskripsikan secara mendalam adat kebudayaan etnik Melayu Pontianak khususnya budaya kemponan.

Ihwal sumber data, peneliti mengambil tiga orang narasumber. Pemilihan tiga orang narasumber tersebut berasal dari tiga daerah di wilayah kebudayaan Melayu Pontianak. Narasumber tersebut antara lain Sataruddin Ramli (Pontianak), Maimun Binti Husin (Kabupaten Mempawah), dan Syarifah Dayang (Kabupaten Kubu Raya). Menurut Badudu (1985: 55-56) pemilihan informan harus memiliki syarat umum seperti:
1. umur informan harus benar-benar dapat mewakili dari suatu masyarakat

2. mutu kebudayaan dan psikologi seorang informan harus luas dan dapat berbicara secara relevan

3. informan hendaknya seorang penutur asli. Ketiga narasumber tersebut telah sesuai dengan persyaratan narasumber.

Dalam penelitian ini pengumpulan data penelitian menggunakan teknik observasi dan wawancara. Observasi dilakukan dengan dua cara yakni observasi sistematis dan observasi nonsistematis. Observasi sistematis dapat dilakukan oleh pengamat dengan menggunakan pedoman sebagai instrumen pengamatan. Sementara observasi non-sistematis dilakukan oleh pengamat yang tidak menggunakan instrumen pengamatan (Arikunto, 2006: 157).

Pada penelitian ini, peneliti mengobservasi perilaku masyarakat Melayu Pontianak menggunakan observasi sistematis dan terbuka. Hal ini dilakukan dengan mengamati secara langsung perilaku khas masyarakat Melayu Pontianak terkait kemponan di tiga wilayah tersebut. Pada saat-saat tertentu, peneliti tidak berpartisipasi langsung tapi hanya bersifat sebagai pemerhati atau pengamat dan tidak terlibat secara langsung dalam percakapan. Namun, dengan penuh ketekunan peneliti menyimak, memperhatikan, dan menyadap hal yang dituturkan oleh para narasumber dan partisipan dalam bersosialisasi 
khususnya yang berkaitan dengan budaya kemponan. Hal ini dilakukan agar komunikasi dan kegiatan yang mereka lakukan berjalan secara alamiah. Dalam proses observasi tersebut, peneliti melakukan pencatatan tentang berbagai hal yang terjadi dan proses pengambilan data secara langsung yang kemudian peneliti interpretasi.

Pada penelitian ini, teknik wawancara dilakukan secara terstruktur. Wawancara dilakukan terhadap tiga orang yang menjadi informan kunci penelitian ini. Selain itu, wawancara juga dilakukan terhadap beberapa individu terutama orang tua yang sangat memahami budaya kemponan. Hal ini dilakukan untuk mendapatkan data dan fakta yang relevan dengan tujuan penelitian.

Instrumen penelitian yang digunakan adalah lembar observasi dan lembar wawancara (interview). Lembar observasi digunakan untuk mencatat secara singkat hal-hal penting saat berada di lingkungan masyarakat Melayu Pontianak dengan pengkondisian terkait gejala kemponan. Lembar wawancara digunakan sebagai pedoman penelitian yaitu menemukan gambaran tentang kemponan menurut narasumber yang memahami adat tersebut. Dengan menggunakan lembar observasi dan wawancara, peneliti lebih fokus untuk mendapatkan informasi yang dibutuhkan.

Penelitian ini menggunakan teknik analisis data kualitatif Huberman dan Miles. Aktivitas dalam menganalisis data kualitatif dilakukan secara interaktif dan berlangsung secara terus menerus sampai tuntas hingga datanya menjadi penuh. Aktivitas dalam menganalisis data tersebut meliputi reduksi data, penyajian data, dan penarikan simpulan atau verifikasi data. Semua hal terkait metodologi penelitian dilakukan secara saksama dan runtun yang tentunya juga ditunjang oleh teori-teori kebudayaan guna mendapatkan hasil penelitian yang baik (Huberman dan Miles, 2014: 20).

\section{HASIL DAN BAHASAN}

\section{Masyarakat Melayu Pontianak dan Tradisi Kemponan}

Secara geografis, kebudayaan Melayu Pontianak berkembang di Kota Pontianak, Kabupaten Mempawah, dan Kabupaten Kubu Raya (Effendi, 2006: 96-97). Penyebaran perkembangan wilayah kebudayaan Melayu Pontianak ini dilatarbelakangi oleh perkembangan kerajaan Melayu di Mempawah dan Pontianak yang memiliki sejarah yang begitu erat. Selain itu, silsilah keturunan kerajaan Mempawah dan Pontianak sangat erat sehingga berkembanglah sebuah budaya Melayu yang kokoh khas Pontianak yang juga diceritakan dalam sastra lisan dan adat tradisinya. Migrasi besar-besaran dari Kerajaan Mempawah ke Pontianak rombongan Sultan Abdurahman AlQadrie yang menikah dengan Putri Cendramidi anak dari raja Mempawah Opu Daeng Manambun juga membuat kebudayaan Pontianak berkembang (Asfar, 2010: 167). 
Pada era modern, wilayah Kerajaan Mempawah dan Pontianak telah berkembang yang secara administratif dinamai dengan Kabupaten Pontianak (sekarang Kabupaten Mempawah) dan Kota Pontianak serta wilayah pemekaran Kabupaten Pontianak yaitu Kabupaten Kubu Raya. Ketiga wilayah membuat khazanah budaya Melayu Pontianak menjadi beragam dan khas.

Selain itu, jika dikaji melalui sensus penduduk, komposisi jumlah penduduk berdasarkan etnisitas, masyarakat Melayu mendominasi khususnya di wilayah Kota Pontianak. Hal ini juga menjadikan identitas kemelayuan masyarakat di wilayah Kota Pontianak tetap lestari dan berkembang serta mendominasi.

\begin{tabular}{|c|c|c|c|c|}
\hline \multirow[t]{2}{*}{ No. } & \multirow{2}{*}{$\begin{array}{c}\text { Wilayah } \\
\text { Administratif }\end{array}$} & \multicolumn{3}{|c|}{ Jumlah Etnis } \\
\hline & & Dayak & Melayu & Tionghoa \\
\hline 1 & $\begin{array}{l}\text { Kota } \\
\text { Pontianak }\end{array}$ & 21.449 & 143.348 & 106.897 \\
\hline 2 & $\begin{array}{l}\text { Kabupaten } \\
\text { Pontianak } \\
\text { (Sekarang } \\
\text { Kabupaten } \\
\text { Mempawah } \\
\text { dan } \\
\text { Kubu Raya) }\end{array}$ & 57.150 & 170.787 & 75.631 \\
\hline \multicolumn{2}{|c|}{$\begin{array}{c}\text { Kebudayaan } \\
\text { Melayu Pontianak }\end{array}$} & 78.599 & 314.135 & 182.528 \\
\hline
\end{tabular}

Tabel 1. Jumlah penduduk berdasarkan etnis di Kota Pontianak dan Kabupaten Pontianak. Sumber: BPS Kalbar, 2010.

Etnis Melayu merupakan etnis mayoritas di Pontianak. Kekhasan kebudayaan Melayu Pontianak mengakibatkan munculnya berbagai kesenian khas. Budaya asli yang dikembangkan antara lain seperti sastra lisan (berpantun, bersyair, prosa, mantra, dan tundang), drama/ teater rakyat mendu dan makyong (Saad, 2003: 67). Ritual unik terkait dengan sugesti tertentu juga ada seperti roborobo, tepung tawar, pantang larang, dan kemponan.

Budaya unik Melayu Pontianak yang menjadi fokus penelitian ini ialah budaya kemponan. Kemponan atau dalam bahasa Indonesia disebut dengan 'kempunan' merupakan sebuah budaya yang berkembang pada kebudayaan Melayu Pontianak.

Secara etimologis kemponan atau kempunan bermakna hal sangat ingin; keadaan selalu ingat karena sangat ingin; dalam kesukaran (kebingungan, kebimbangan, serba salah, merugi, dsb); keadaan merasa sangat celaka karena amat kecewa (https:// kbbi.kemdikbud.go.id/entri/ kempunan). Secara definisi, istilah kemponan merupakan sebuah ungkapan yang dimanifestasikan dengan rasa takut atau cemas yang timbul karena adanya sugesti dalam diri seseorang, akan terjadi hal buruk akibat dari seseorang menolak tawaran untuk makan dan minum (Wawancara Satarrudin Ramli, Pontianak, Januari 2015).

Kemponan juga dapat diartikan sebagai sebuah konsep menjamah hidangan yang disajikan walaupun sedikit dengan pola perilaku tertentu (Wawancara Maimun binti Husin, Mempawah, Januari 2015). Bagi masyarakat Melayu, selera seseorang tidak boleh dipermainkan. Jika seseorang berkeinginan untuk sekadar 
mencicipi sebuah hidangan namun tidak tersampainya hajat orang tersebut maka akan dikhawatirkan timbul rasa was-was dan takut terjadi sesuatu.

Menurut kepercayaan masyarakat Melayu Pontianak, melanggar kemponan sangat besar risikonya (wawancara Syarifah Dayang, Kubu Raya, Februari 2015). Orang yang melanggar hal tersebut bisa terkena musibah (bala). Contoh terjadinya bala yaitu ketika seseorang menolak untuk sekadar menjamah makanan yang akibatnya orang tersebut terjatuh dan terluka saat beraktivitas. Musibah pun dapat terjadi hingga merenggut nyawa. Hingga saat ini, budaya tersebut masih dipegang kuat oleh sebagian besar masyarakat Melayu Pontianak bahkan sudah menjadi sebuah kebiasaan seharihari.

Budaya kemponan hampir mirip dengan budaya pantang larang. Hal yang membedakannya adalah tentang "rasa" berupa sugesti negatif yang muncul khusus berkaitan dengan makanan maupun minuman sedangkan pada pantang larang berlaku secara umum dan lebih difokuskan pada nilai tata karma dalam kehidupan seharihari. Contoh pantang larang misalnya perempuan dilarang duduk bersantai di depan pintu. Mitosnya, jika hal tersebut dilakukan maka perempuan tersebut akan sulit mendapatkan jodoh. Pantang larang tersebut bermakna positif untuk mengingatkan bagi perempuan agar berperilaku sopan dan tidak menghalangi jalan. Masyarakat Melayu menilai bahwa perempuan yang duduk di depan pintu dianggap tidak sopan. Pandangan masyarakat terkait sopan santun seorang perempuan terutama anak gadis menjadi tolak ukur pertama untuk meminangnya menjadi seorang istri. Laki-laki akan mengurungkan niatnya untuk menikahi perempuan yang dianggap tidak menjunjung tinggi sopan santun.

Selain makna kata kemponan, perlu diketahui juga mengenai penyebab terjadinya kemponan dan cara mencegahnya serta nilai yang terkandung di dalam budaya tersebut. Manusia membuat suatu budaya pasti diikuti oleh alasan yang masuk akal. Terkait hal ini, maka nilai budaya kemponan yang termasuk ke dalam kearifan lokal akan diuraikan secara khusus dalam kajian ini.

\section{Sebab Terjadinya dan Media Penyebab Kemponan}

Sebagai suatu identitas yang diimajinasikan, Melayu memiliki dimensi mistis (Prentiss dalam Gaspersz, TT: 3). Melayu memiliki referensi simbolis untuk menegosiasikan perbedaan-perbedaan demi mencapai ikatan kultural dengan nilai-nilai yang dihidupi bersama. Tidak jarang nilai-nilai dalam kehidupan orang Melayu diajarkan lewat sugesti (seperti kemponan) yang dikaitkan dengan mitos.

Hal ini dipertegas oleh Shah dan Wahid (2010: 182) bahwa mitos dalam budaya Melayu bukan hanya sebuah warisan namun merupakan jelmaan dari berbagai adat istiadat dan 
kepercayaan yang masih dihayati. Perbincangan tentang mitos dalam kajian kosmologi Melayu selalu berkaitan dengan ritual, magis, dan elemen-elemen animisme.

Masyarakat Melayu Pontianak percaya bahwa kemponan akan terjadi bila seseorang menolak ajakan orang lain untuk menyantap makanan atau minuman yang telah disajikan (Wawancara Satarudin Ramli, Pontianak, Januari 2015). Hal ini dipercaya akan mengundang sugesti negatif yang menimbulkan bala atau celaka pada orang tersebut. Hal ini juga sejalan dengan pendapat Effendi (dalam Mustansyir, 2017: 14) bahwa masyarakat Melayu di Kalimantan Barat memandang tradisi kemponan sebagai sebuah penanda (signifier) yang menjadi kebiasaan, sehingga membentuk petanda (signifed) berupa mental yang sudah dijalankan sejak lama secara turun temurun.

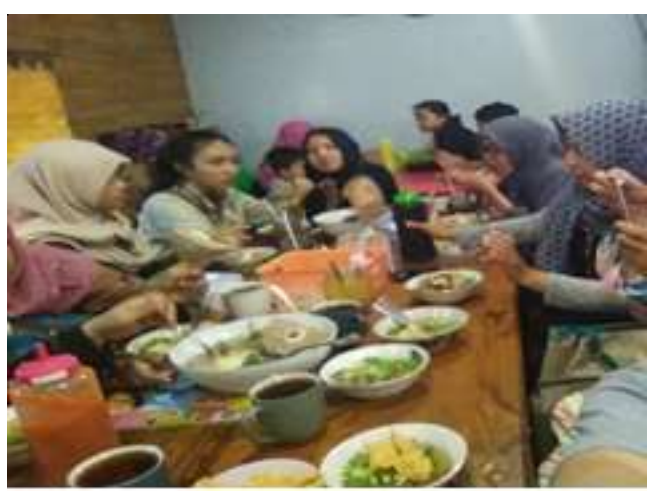

Gambar 1. Meninggalkan sajian saat ditawarkan disuatu pertemuan akan menimbulkan kemponan. Sumber: dokumentasi pribadi.
Hubungan antara kebiasaan dan mental dalam kemponan dibalut dalam mitos sehingga terus menerus diwariskan. Shah dan Wahid, (2010: 186) menegaskan bahwa mitos akan menjelma menjadi idealisme dalam masyarakat dan membuka sebuah pemahaman terhadap proses kognitif yang mempengaruhi tingkah laku hingga kini.

Secara umum, semua makanan dan minuman dapat mengundang dan menyebabkan terjadinya kemponan. Namun, ada beberapa makanan dan minuman yang dianggap paling sakral dan paling cepat mengundang terjadinya kemponan. Makanan dan minuman tersebut dapat dikelompokkan sebagai berikut.

\section{a. Makanan}

Ada beberapa makanan yang dianggap mampu mempercepat proses terjadinya kemponan dan sangat sakral untuk ditolak dan dikonsumsi. Makanan tersebut antara lain sebagai berikut.

1) Nasi dan Olahannya

Nasi yang berasal dari padi merupakan makanan pokok masyarakat Melayu Pontianak. Nasi merupakan makanan yang dianggap paling sakral bagi masyarakat Melayu Pontianak (Wawancara Maimun binti Husin, Mempawah, Januari 2015). Selain nasi yang disajikan sebagai panganan utama, olehan dari nasi seperti nasi goreng juga dianggap sakral. 
Dalam kajian historis, rasa hormat manusia animisme khususnya masyarakat Melayu Nusantara terhadap padi sangat besar. Mereka menganggap bahwa padi mempunyai sifat seperti manusia. Padi mempunyai "semangat (daya hidup)" yang harus dijaga supaya jangan "lari (hilang)" akibat sesuatu. Banyak usaha yang dilakukan terutama pada bibit padi seperti ditepung-tawari, diberi "makan", ditegur dengan lemah lembut dan lain-lain yang semuanya dimaksudkan agar bibit itu tetap mempunyai semangat yang teguh dan berisi. Hal ini dilakukan agar jika ditanam nanti akan menghasilkan bulirbulir padi yang lebat, padat, besar, dan berlipat ganda (Husny, 1986: 45).

Jika kita kaji lebih dalam, terdapat hubungan antara nasi sebagai sebab kemponan dengan budaya pantang larang dan sastra lisan Melayu Pontianak. Ada sebuah pantang larang yang menyatakan bahwa pedaringan (wadah menampung) beras tidak boleh habis isinya dan jika kita mengambil beberapa canting (wadah kecil sebesar kaleng susu sebagai satuan memasak nasi) beras untuk masak hendaklah canting tersebut diisi penuh lagi dengan beras sambil membacakan selawat nabi. Namun ada pula budaya Hindu yang masih dipakai yaitu memasukkan beras di dalam canting dan mengikatnya dengan kain kuning dan simpul berwarna kuning dengan membacakan mantra dan disimpan di pedaringan agar beras terus bertambah dan rezeki tidak akan pernah putus.
Selain itu, sastra lisan seperti cerita rakyat dari Mempawah yaitu "nasi menangis" juga menggambarkan bahwa nasi tidak boleh dibuang dan mubazir. Pesan tersebut digambarkan jelas oleh masyarakat Melayu Pontianak bahwa sebutir nasi yang jatuh dan terselip di lantai kayu dapat "menangis". Hal ini menunjukkan betapa tingginya penghargaan terhadap nasi sebagai makanan pokok. Kemponan juga pastinya memiliki keterkaitan dengan kisah dan pantang larang tersebut. Hal ini tersirat makna bahwa beras merupakan kebutuhan pokok yang harus diusahakan dan dijaga agar tidak mubazir.

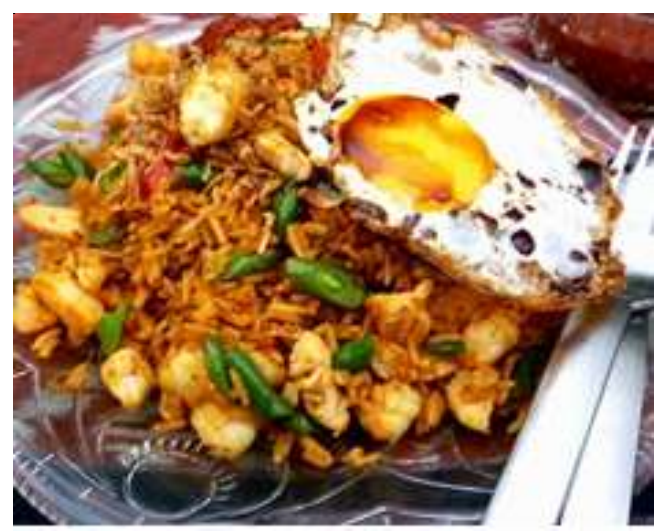

Gambar 2. Nasi goreng (olahan nasi). Sumber: dokumentasi pribadi.

2) Pulut (Ketan) dan Olahannya Pulut atau ketan merupakan dari tumbuhan keluarga padi-padian yang juga dianggap memiliki kekuatan untuk mengundang terjadinya kemponan. Hal ini karena pulut sering digunakan dalam upacara adat. Pada acara pernikahan, tak jarang masyarakat Melayu Pontianak menyajikan pulut di pokok 
Handep Jurnal Sejarah dan Budaya Vol. 3, No. 1, Desember 2019, hlm. 101-120

telok sebagai satu di antara bahan hantaran pengantin.

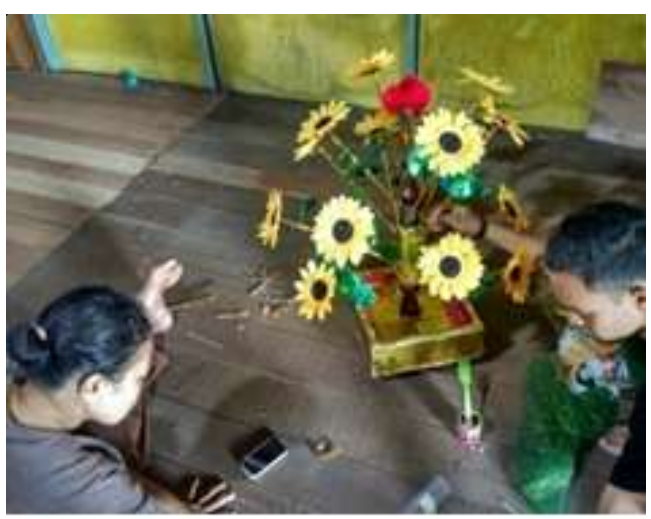

Gambar 3. Pokok telok yang sedang dihias dan akan disajikan nasi pulut kuning dibawahnya tatanannya. Sumber: dokumen pribadi.

Pulut yang memiliki tekstur dan aroma yang khas ketika dibumbui dengan santan memberikan rasa yang menarik. Banyak sekali olahan makanan yang berbahan dasar pulut kudapan dalam kebudayaan Melayu Pontianak seperti ketupat pulut, lemang, pengkang, dan lempar. Hidangan tersebut dijadikan camilan ataupun 'makan besar' dan dianggap istimewa oleh masyarakat sebagai pengganti nasi.

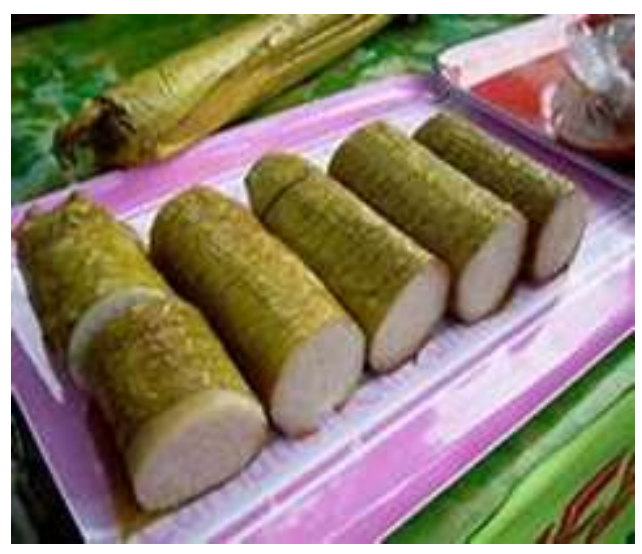

Gambar 4. Lemang (olahan Pulut). Sumber: dokumentasi pribadi.
Kedudukannya yang disamakan dengan nasi berpengaruh terhadap statusnya sebagai makanan yang sakral untuk ditolak saat disajikan. Hal ini menjadikan pulut sebagai satu di antara makanan yang dapat menyebabkan kemponan (Wawancara Syarifah Dayang, Kubu Raya, Februari 2015).

\section{3) Kudapan atau Camilan}

Jenis kudapan yang paling dianggap sakral bagi masyarakat Melayu Pontianak adalah lempeng sagu. Camilan lempeng sagu adalah olahan tepung sagu yang dicampur dengan parutan kelapa dan dipanggang dengan sedikit minyak dan disajikan dengan taburan gula pasir di atasnya. Makanan ini merupakan makanan tradisional khas Mempawah dan juga dikenal di Kota Pontianak untuk dijadikan camilan saat sarapan pagi dan biasanya beserta air kopi.

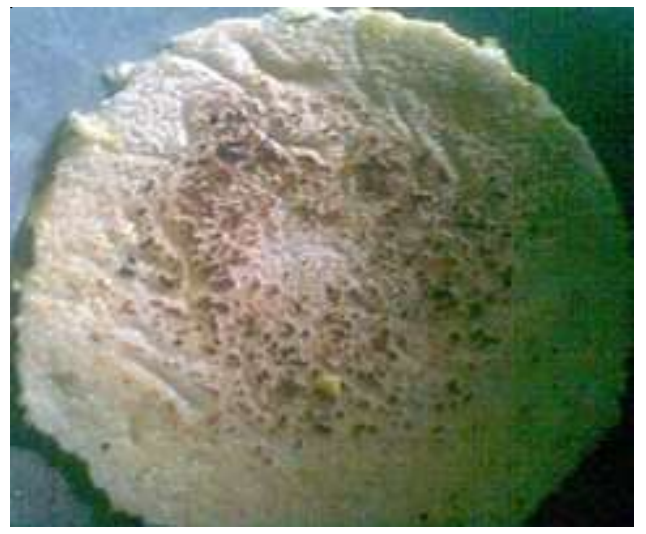

Gambar 5. Lempeng sagu.

Sumber: dokumentasi pribadi.

Sagu sebagai bahan pengganti beras juga disamakan statusnya sebagai bahan makanan pokok pada zaman dahulu. Olahan sagu umumnya 
dijadikan makanan yang mengenyangkan layaknya nasi seperti mi sagu khas Pontianak dan lempeng sagu khas Mempawah. Hal inilah yang membuat olahan sagu juga dapat menyebabkan terjadinya kemponan.

Kebiasaan masyarakat Melayu Pontianak dalam mengkonsumsi olahan sagu juga diceritakan dalam sebuah sastra lisan di Mempawah. Cerita tersebut mengisahkan tentang mudarat lempeng sagu yang telah menyelamatkan seorang ibu dari perampok yang hendak beraksi di rumahnya. Perampok tersebut mengurungkan niatnya karena takut terkena tulah (pamali atau sial) karena telah memakan lempeng saguk yang secara tidak sengaja tersaji di dapur ibu tersebut (Wawancara Maimun binti Husin, Mempawah, Februari 2015).

\section{b. Minuman}

Minuman yang sangat terkenal untuk mengundang kemponan adalah air kopi (wawancara Satarudin Ramli, Pontianak, Januari 2015). Air kopi dianggap sangat cepat mendatangkan kemponan karena merupakan minuman utama yang biasa disajikan dalam kehidupan sehari-hari dan bisa dikatakan sebagai minuman kebanggaan masyarakat Melayu Pontianak.

Air kopi disajikan dalam kegiatan adat maupun sebagai teman camilan. Masyarakat Melayu Pontianak sangat pandai meracik kopi dan menghidangkannya. Contoh konkretnya adalah adanya sebuah istilah 'kopi Mak Jande' sebutan negatif bagi orang yang tidak terampil membuat air kopi. Kopi yang disajikan terlalu encer dan air yang digunakan untuk menyeduhnya tidak terlalu panas sehingga mengurangi cita rasa.

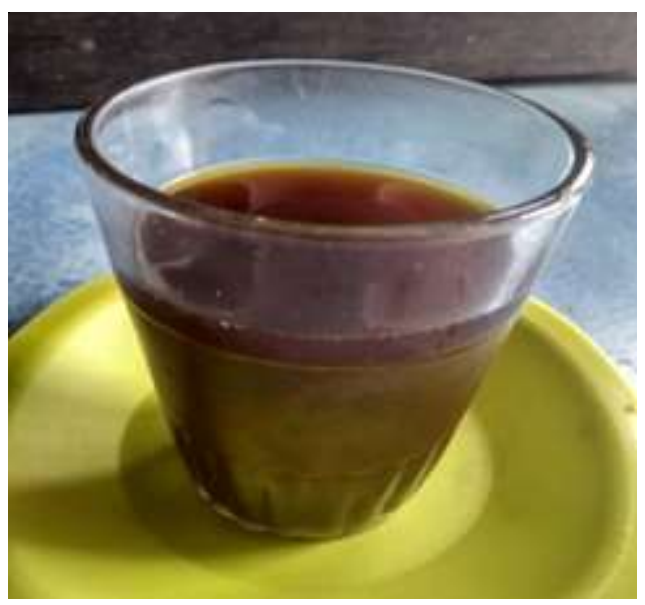

Gambar 6. Minuman kopi. Sumber: dokumentasi pribadi.

Minuman kopi dianggap penting oleh masyarakat Melayu Pontianak menjadikannya sebagai minuman pokok yang mirip statusnya sebagai makanan pokok (nasi). Hal ini membuat minuman kopi lebih cenderung membuat seseorang mengalami kemponan. Selain kopi, minuman lain juga dapat membuat efek kemponan. Namun tidak seperti minuman kopi yang dianggap paling cepat membuat peluang terjadinya nahas (kecelakaan atau bala) akibat kemponan terjadi (Wawancara Maimun binti Husin, Mempawah, Februari 2015).

\section{Pola Pencegahan Kemponan}

Kemponan dapat terjadi bukan hanya adanya rasa takut ketika menolak tawaran untuk makan dan minum, 
namun juga memiliki beberapa pola dan juga melahirkan beberapa istilah baru sebagai "penangkal atau pencegah" terjadinya bala atau musibah. Pola-pola tersebut terdiri atas tiga hal berikut.

\section{a. Perilaku Jamah}

Perilaku jamah merupakan pola pertama yang memunculkan tindakan khas yang secara etimologis berarti menyentuh dengan jari; meraba; memegang (KBBI Edisi V Offline, 2017). Istilah ini muncul saat seseorang ditawari hidangan namun orang tersebut bergegas pergi dan segera melakukan aktivitas lain sehingga tidak sempat untuk makan maupun minum. Tindakan yang harus dilakukan pada situasi tersebut agar tidak terjadi kemponan yang berujung pada bala adalah dengan cara menjamah makanan atau minuman tersebut.

Cara menjamah sangatlah unik dan memiliki pola yang berbeda sesuai jenis hidangannya berikut.

1) Menjamah Makanan Pokok dan Kudapan

Makanan pokok seperti nasi dan berbagai jenis kudapan cara menjamahnya cukup mengambil sebagian kecil dari makanan tersebut dengan jari tangan lalu sentuhkan dengan lidah. Selain cara tersebut, ada pula cara yang dianggap praktis yaitu dengan mengambil sebagian kecil dari makanan tersebut dengan jari tangan lalu sentuhkan di bagian leher hingga pangkal leher (Wawancara Maimun binti Husin, Mempawah, Februari
2015). Penyentuhan makanan di bagian leher dianalogikan bahwa orang tersebut telah mencicipi dan makanan tersebut telah masuk ke kerongkongan untuk dicerna.

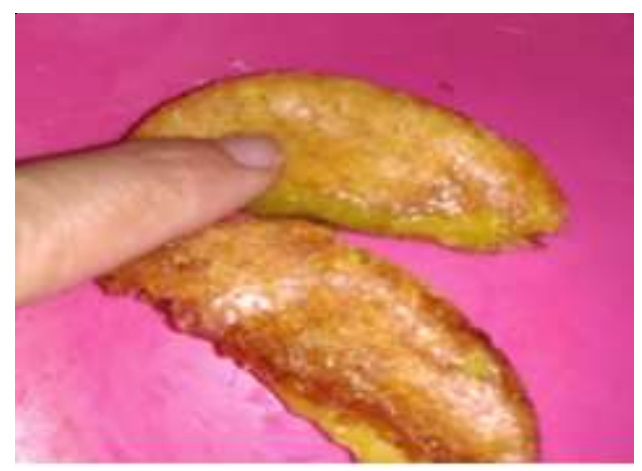

Gambar 7. Jamah pada kudapan kue pancong. Sumber: dokumentasi pribadi.

2) Menjamah Minuman

Untuk minuman tidak jauh berbeda cara menjamahnya. Hal yang membedakannya hanya pada wujud objeknya saja yaitu berupa cairan atau air bukan dalam wujud padat. Karena wujudnya tersebut, maka menjamahnya cukup dengan menyentuhkan jari tangan ke air tersebut (misalnya kopi atau teh) dan kemudian menyentuhkannya ke lidah.

\section{b. Perilaku Campalet Kemponan}

Istilah 'cempalet kemponan' muncul ketika seseorang ditawari hidangan ketika berada di lingkungan "keluarga", namun orang tersebut terlanjur pergi dan segera melakukan aktivitas lain sehingga tidak sempat untuk menjamah. Namun, ia teringat untuk merasakan dan mencicipi hidangan yang disajikan oleh keluarganya itu dan sangat terbayang-bayang akan 
kenikmatan sajian tersebut. Ia merasa takut sehingga menimbulkan pikiran terjadinya kemponan. Tindakan yang harus dilakukan saat situasi seperti ini agar tidak terjadi kemponan yang berujung pada bala atau musibah adalah dengan cara 'cempalet' makanan atau minuman tersebut.

Cempalet murupakan istilah lain dari 'jamah' yang berasal dari kata 'palet' dalam bahasa Melayu Pontianak yang berarti menyentuh benda atau sesuatu yang lembut dengan jari telunjuk. Biasanya objek yang disentuh berupa krim seperti selai dan sebagainya. Istilah ini membedakannya dengan pola pertama yaitu ‘jamah'. Pada kasus ini, makanan yang berupa benda padat dan cairan pun tetap memakai istilah 'cempalet'.

Tindakannya pun sangat sederhana yaitu cukup menyentuhkan jari tangan ke lidah dan menyentuhkannya lagi ke leher hingga pangkal leher sambil mengucapkan "cempalet kemponan ... (menyebutkan hidangan yang disajikan)". Misalnya orang tersebut lupa mencicipi buah durian yang disajikan oleh ayahnya di rumah, maka ia menyebutkan "cempalet kemponan durian." Air liur yang disentuhkan pada leher akan menciptakan sensasi "sakral atau magis" yang luar biasa dengan menganalogikan bahwa orang tersebut telah mencicipi dan makanan tersebut telah masuk ke kerongkongan untuk dicerna.

\section{c. Perilaku Palet Kemponan}

Pola yang terakhir ini memiliki perbedaan yang paling kentara. Kemponan juga akan terjadi jika seseorang yang dalam perjalanan melihat makanan dan minuman yang disajikan atau dijual di jalan atau pusatpusat pertokoan. Orang tersebut sebenarnya hanya melihat hidangan yang sangat ia gemari lalu ia tinggalkan dengan berbagai alasan (misalnya tidak memiliki cukup uang untuk membelinya). Beberapa selang waktu kemudian keinginannya untuk mencicipi hidangan tersebut semakin memuncak. Ia merasa sangat ingin menikmati hidangan itu sehingga muncullah anggapan bahwa hal tersebut bisa mengundang terjadinya kemponan.

Tindakan pertama yang harus dilakukan orang tersebut adalah melakukan "palet kemponan" Cara melakukannya tidak jauh berbeda dengan pola ke-2. Hal yang membedakannya terletak pada penyebab terjadinya kemponan. Pola "memalet" juga sama dan yang membedakannya hanya pada sugesti yang berupa ucapan "palet kemponan ...(menyebutkan hidangan yang sangat ia inginkan)". Misalnya orang tersebut sangat ingin sekali mencicipi ikan asam pedas yang ia lihat di rumah makan Melayu, maka ia menyebutkan "palet kemponan ikan asam pedas." 
Secara umum, ketiga pola kemponan dan pembentukan istilah di dalamnya memang sangat mirip dan berkaitan. Namun, ketiga pola tersebut tetap memiliki perbedaan dan ciri khas masing-masing. Berikut letak perbedaannya yang disajikan secara ringkas.

\begin{tabular}{|c|c|c|c|}
\hline \multirow{2}{*}{$\begin{array}{c}\text { Istilah } \\
\text { dalam } \\
\text { kemponan }\end{array}$} & \multicolumn{3}{|c|}{ Konteks penyebab } \\
\hline & $\begin{array}{l}\text { Ditawarkan } \\
\text { hidangan oleh } \\
\text { pemilik rumah } \\
\text { kepada tamu, } \\
\text { anggota } \\
\text { keluarga atau } \\
\text { teman sejawat } \\
\text { namun } \\
\text { menolaknya } \\
\text { dengan sopan } \\
\text { dengan alasan } \\
\text { sudah makan } \\
\text { atau minum } \\
\text { sebelumnya } \\
\text { atau perut } \\
\text { dalam } \\
\text { keadaan } \\
\text { penuh saat itu }\end{array}$ & $\begin{array}{l}\text { Hendak } \\
\text { mencicipi } \\
\text { makanan atau } \\
\text { minuman } \\
\text { namun lupa } \\
\text { dan terlanjur } \\
\text { pergi tapi pada } \\
\text { saat tertentu } \\
\text { teringat bahwa } \\
\text { sebelumnya } \\
\text { ada keinginan } \\
\text { untuk makan } \\
\text { atau minum }\end{array}$ & $\begin{array}{l}\text { Berkeinginan } \\
\text { untuk makanan } \\
\text { atau minuman } \\
\text { namun tidak } \\
\text { bisa memakan } \\
\text { atau meminum } \\
\text { karena alasan } \\
\text { tertentu seperti } \\
\text { tidak mampu } \\
\text { membelihnya, } \\
\text { atau makanan } \\
\text { dan minuman } \\
\text { tersebut sedang } \\
\text { tidak tersedia }\end{array}$ \\
\hline Jamah & $\mathbf{V}$ & - & - \\
\hline Cempalet & - & $\mathbf{V}$ & - \\
\hline Palet & - & & V \\
\hline
\end{tabular}

Tabel 2. Konteks penyebab yang membedakan tindakan penangkal kemponan.

Berdasarkan wujud hidangan, terdapat versi lain yang menyebut bahwa "penangkal atau pencegah" melalui perilaku cempalet kemponan dan palet kemponan dengan cara yang berbeda. Cara yang berbeda itu dengan menyentuhkan jari telunjuk ke lidah dan menyentuhkannya lagi ke dahi (Wawancara Satarudin Ramli, Pontianak, Februari 2015). Pola ini sepertinya masih terpengaruhi oleh budaya Hindu yang "memaletkan" sejenis pewarna merah ke dahi sebagai pemberkatan. Pola jenis ini sangat jarang dilakukan oleh masyarakat
Melayu Pontianak dan cenderung ditinggalkan.

\begin{tabular}{|c|c|l|l|}
\hline \multirow{2}{*}{$\begin{array}{l}\text { Istilah } \\
\text { dalam } \\
\text { kempon- }\end{array}$} & \multicolumn{3}{|c|}{ Tindakan berdasarkan wujud hidangan } \\
\cline { 2 - 4 } & $\begin{array}{l}\text { Menjamah } \\
\text { makanan/ } \\
\text { minuman. }\end{array}$ & $\begin{array}{l}\text { Mengambil } \\
\text { sebagian kecil } \\
\text { dari makanan } \\
\text { tersebut dengan } \\
\text { jari tangan lalu } \\
\text { sentuhkan } \\
\text { dengan lidah. }\end{array}$ & $\begin{array}{l}\text { Mengambil } \\
\text { sebagian kecil dari } \\
\text { makanan tersebut } \\
\text { dengan jari tangan } \\
\text { lalu sentuhkan di } \\
\text { bagian leher } \\
\text { hingga pangkal } \\
\text { leher. }\end{array}$ \\
\hline jamah & $\mathbf{V}$ & - & - \\
\hline cempalet & - & $\mathbf{V}$ & - \\
\hline Palet & - & - & Vinuman \\
\hline
\end{tabular}

Tabel 3. Tindakan yang harus dilakukan sesuai hidangan.

\section{Nilai Sosial Budaya Dalam Budaya Kemponan Masyarakat Melayu Pontianak}

Nilai budaya adalah suatu konsepsi yang merupakan kesatuan ide yang sifatnya abstrak, yang hanya berada di dalam pikiran manusia. Konsepsikonsepsi tersebut mengenai hal-hal yang dianggap paling prinsip dan mendasari oleh masyarakat, sehingga merupakan suatu hal yang wajib atau harus dilakukan. Agar dapat melakukan hal-hal yang prinsip tersebut harus ada suatu pedoman dan tuntunan yang berupa norma ataupun peraturan yang bersifat konkret.

Menurut Koentjaraningrat (2015) sistem nilai budaya biasanya berfungsi sebagai pedoman tertinggi bagi kelakuan manusia. Sistem tata kelakuan manusia lain yang tingkatnya lebih konkret, seperti aturan-aturan khusus, hukum, dan norma-norma semuanya juga berpedoman pada sistem nilai budaya. 
Selanjutnya C. Kluckhohn dalam Koentjaraningrat (2015: 42-47) juga mengemukakan lima masalah dasar dalam kehidupan manusia berikut.

a. Masalah mengenai hakikat dari hidup yang menyatakan ada kebudayaan yang mengonsepsikan bahwa pada hakikatnya hidup ini buruk dan menyedihkan. Ada kebudayaan yang mengonsepsikan bahwa pada hakikatnya kehidupan ini menyenangkan.

b. Masalah mengenai hakikat dari karya manusia yang menyatakan kebudayaan di dunia ini dalam memandang hasil karya manusia itu pada hakikatnya beraneka ragam, ada kebudayaan yang memandang bahwa pada hakikatnya karya itu memungkinkan hidup, karya manusia itu memberi kedudukan dalam masyarakat, dan karya itu suatu gerak hidup untuk menghasilkan lebih banyak karya lagi.

c. Masalah mengenai hakikat kedudukan manusia dalam ruang dan waktu yang ada kehidupan yang mengandung penting masa lalu dalam kehidupan manusia. Ada kebudayaan yang beroroentasi sejauh mungkin terhadap masa yang akan datang.

d. Masalah mengenai hakikat dari hubungan manusia dengan alam sekitarnya menyatakan ada kebudayaan yang memandang alam itu sebagai suatu hal yang bisa dilawan oleh manusia, dan mewajibkan manusia itu melakukannya. e. Masalah mengenai hakikat dari hubungan manusia dengan manusia yang menyatakan terhadap konsep mengenai hal itu. Konsepsi-konsepsi yang dimaksud yakni ada kebudayaan yang mementingkan hubungan vertikal antara manusia dengan sesamanya. Dalam pola kelakuannya, manusia yang hidup dalam kebudayaan ini akan berpedoman pada tokoh-tokoh, pemimpin, orang-orang senior atau orang-orang atasan, artinya orientasi mereka hanya kepada orang-orang yang dianggap penting.

Ada kebudayaan yang lebih mementingkan hubungan horizontal antara manusia dengan manusia. Orang yang hidup dalam konsepsi ini membutuhkan sesamanya yang sederajat dan usahanya untuk bekerjasama dan saling menjalin hubungan baik dengan sesama tetangganya baik yang statusnya sama maupun yang berbeda dianggap penting.

Berdasarkan kelima uraian di atas, kehidupan manusia yang ada dalam sistem budaya pada akhirnya berhubungan erat dengan nilai-nilai budaya merupakan abstraksi dari adat istiadat yang merupakan konsepkonsep mengenai apa yang hidup dalam masyarakat. Hal positif yang terdapat dalam sebuah budaya termasuk kemponan dapat diambil hikmahnya untuk memperkaya khazanah sebagai sebuah kearifan lokal masyarakat Melayu Pontianak. Kemponan merupakan perwujudan budaya 
masyarakat Melayu yang di dalam terkandung nilai kearifan lokal yaitu:

\section{1) Nilai Budaya Saling Menghargai Sesama Manusia}

Apabila masyarakat Melayu berkunjung ke rumah kerabat, biasanya akan dihidangkan makanan dan minuman. Adat masyarakat Melayu mengajarkan bahwa melayani tamu dengan baik merupakan hal penting. Sebagai tamu, jika dihidangkan makanan dan minuman namun kita tidak menyentuh hidangan itu, maka pasti tuan rumah akan berkecil hati. Supaya tidak menyinggung perasaan tuan rumah, hendaklah masyarakat Melayu menjamah sedikit, supaya tidak kemponan. Orang Melayu percaya, walaupun tamu belum berselera untuk menjamah hidangan, secara tidak sadar, hati sudah berkata-kata tentang makanan yang terhidang. Makanan itu harus dijamah supaya kita tidak akan teringat tentang makanan itu apabila pulang. Tindakan menjamah makanan dilakukan untuk mencegah terjadinya kemponan.

Budaya kemponan digambarkan dalam cerita rakyat Melayu Sambas 'Batu Ballah Batu Betangkup'. Dikisahkan ada seorang ibu (janda) dengan dua orang anak yang masih ke sebuah desa pesisir. Sang ibu sangat ingin menyantap olahan telur tembakul dan menyajikannya pula untuk anakanaknya tersebut. Namun malang, saat sang Ibu pergi sbentar untuk mengerjakan sesuatu ia mendapati anak-anaknya telah menghabiskan makanan tersebut tanpa sisa. Ia pun sangat kecewa dan bersedih hati dan meratapi dirinya sambil bernyanyi sedih di antara puaka batu belah (batu keramat) hanya karena kemponan telur tembakul. Batu keramat yang semula hanya bongkahan batu terbelah itu tibatiba bergerak dan menghimpit sang ibu yang sedang meratapi diri karena merasa kemponan. Anak-anaknya pun merasa menyesal karena tidak mendengarkan pesan ibunya untuk disisakan makanan yang sangat ibunya dambakan itu.

Pada cerita tersebut mengambarkan bahwa anak harus menghargai orang tua, menjaga amanah, dan tidak mementingkan diri sendiri. Melalui cerita ini juga, konsep kemponan bagi masyarakat Melayu dapat ditilik dari 'world view' dapat berujuk pada bala hingga kematian yang mengenaskan.

\section{2) Nilai Budaya Menghargai Alam}

Budaya Melayu yang tersebar luas di kepulauan nusantara dan Asia Tenggara akan mengalami perkembangan sesuai dengan hubungannya dengan lingkungan dan alam. Hal inilah yang menjadi perbedaan antara Melayu yang terdapat di suatu daerah dengan daerah yang lain. Menurut Sunandar (2015: 2) ekspresi budaya Melayu yang ada di Kalbar misalnya Melayu Sambas akan berbeda dengan Melayu Pontianak dan Mempawah. Perbedaan tersebut tentu saja tidak dapat dilepaskan dari faktor sejarah dan pengalaman orang-orang Melayu dengan alam dan lingkungannya. 
Alam sebagai anugerah Sang Maha Pencipta menyediakan segala kebutuhan hidup manusia. Satu di antara kebutuhan itu adalah beras sebagai kebutuhan pokok dalam peradaban Melayu. Dalam kajian kemponan, beras yang diolah menjadi nasi dikhawatirkan akan mengundang kemponan. Hal ini wajar karena nasi yang manusia nikmati memerlukan proses yang panjang untuk kemudian konsumsi.

Nasi yang dikonsumsi masyarakat telah melalui banyak tahapan sehingga perlu dihargai. Dengan proses yang panjang mulai dari pembibitan padi, penanaman, panen padi, pengolaha menjadi bulir beras hingga dimasak menjadi nasi memerlukan perjuangan dan waktu yang tidak sedikit. Tidak jarang berbagai bencana alam seperti banjir, angin topan dan sebagainya akan menghancurkan dan menggagalkan panen padi. Disinilah diajarakan bahwa kemponan memberikan pendidikan moral tentang menghargai alam yang sebenarnya tidak sesederhana yang dipikirkan manusia.

Nilai dalam menghargai alam dan prosesnya yang panjang tersebut diaplikasikan dalam budaya kemponan dan budaya lainnya. Masyarakat Melayu diajarkan untuk menjaga, mengolah, dan mensyukuri hasil alam yang diwujudkan dalam berbagai ritual tertentu. Seperti yang dicontohkan oleh Sunandar (2015: 2) bahwa budaya Melayu semacam ini telah diaplikasikan dalam ritual antar ajong (Melayu Sambas), buang-buang (Melayu
Pontianak), dan robo-robo (Melayu Mempawah) yang berupa ritual melarung sesajian ke laut. Inti dari berbagai budaya termasuk kemponan tentunya memiliki pembelajaran bahwa masyarakat Melayu sepatutnya mensyukuri hasil alam dan mengkonservasi serta mengeksplorasinya dengan bijak.

\section{3) Nilai Budaya Religi}

Kemponan merupakan suatu kepercayaan turun-temurun dan dapat menjawab fenomena alam serta hubungannya terhadap hidup dan mati manusia (wawancara Syarifah Dayang, Februari 2015). Kepercayaan kemponan bisa mengantarkan pada syirik dalam konsep agama Islam. Misalnya, seseorang tidak menjamah makanan dan kemudian meninggal dunia. Ada orang yang mengatakan, "kalaulah almarhum/ almarhumah makan dahulu sebelum beraktivitas, dia mungkin tidak meninggal dunia". Tanggapan tersebut menjadi syirik karena tidak mempercayai qada dan qadar Tuhan. Kesimpulannya, tiada istilah atau konsep 'kemponan' dalam agama Islam.

Kaitannya dengan kajian ini, maka dimensi isi dalam konsep kemponan itu menyangkut makna religius tentang sebab-sebab kematian. Sedangkan dimensi lain dari kemponan menyangkut tentang kepatuhan terhadap nilainilai di luar kuasa manusia khususnya ketuhanan. Konsep kepatuhan dan penerimaan apa adanya tentang takdir, menghargai manusia, dan alam merupakan perwujudan budaya religi 
masyarakat Melayu. Kemponan sebenarnya digunakan sebagai sarana untuk menyampaikan pesan moral dan tuntunan cara hidup yang baik bagi masyarakat Melayu.

Islam sebagai agama mayoritas yang dianut masyarakat Melayu memandang bahwa takdir baik dan buruk dalam konsep qada, qadar, dan tawakal. Jika ditilik antara kemponan dan konsep tersebut, seyogyanya ada sebuah kaitan yang berujung pada pandangan tentang takdir yang dimulai dari sugesti dan dilakukan lewat usaha. Hal yang membedakan keduanya hanya terletak pada kemponan yang cenderung mengarah pada takdir buruk (negatif) yang akan terjadi yang disebabkan oleh keinginan sehingga perlu dicegah terjadinya bala (takdir buruk).

\section{SIMPULAN}

\section{Simpulan}

Kemponan merupakan sebuah budaya yang muncul karena adanya sugesti negatif yang disebabkan oleh keinginan yang tidak tersampaikan. Jika keinginan tersebut tidak tersampaikan atau bahkan disepelekan maka akan mengundang bala (musibah). Terjadinya kemponan dapat dicegah dengan perilaku khas yang disebut jamah atau cempalet. Hal ini bersumber dari pola pikir individu masyarakat Melayu Pontianak jika melanggar ajakan seorang untuk makan dan minum serta mengabaikan keinginan pada sesuatu. Hal ini merupakan ciri umum dari sebuah kearifan lokal masysrakat
Melayu Pontianak dalam menghargai individu, sesama manusia, alam, dan sang pencipta. Secara khusus ada tiga nilai yang diajarkan yaitu yaitu 1) nilai budaya saling menghargai sesama manusia, 2) nilai budaya menghargai alam, dan 3) nilai religi.

\section{Saran}

Diharapkan akan ada peneliti yang mendalami berbagai hal terkait budaya Melayu pada penelitian sejenis. Hal ini penting untuk menemukan hikmah atau maksud positif dari adat istiadat ataupun budaya pada etnik tertentu yang telah dibangun dari zaman dahulu. Selain itu, perlu adanya penelitian yang khusus membahas mengenai budaya kemponan dan budaya pantang larang. Apakah keduanya memiliki keterkaitan ataupun merupakan satu kesatuan bagian kebudayaan yang menyangkut pola pikir masyarakat Melayu.

\section{DAFTAR SUMBER}

Anwar, Khaidir. 1995. Beberapa Aspek Sosio-Kultural Masalah Bahasa. Yogyakarta: UGM.

Arikunto, S. 2006. Prosedur Penelitian: Suatu Pendekatan Praktik. Jakarta: Rineka.

Asfar, Dedy Ari. 2010. Bahasa Ibu Sebagai Identitas Etnik: Sosiolingusitik Melayu di Kota Pontianak. Prosiding Pada Seminar Nasional Pelestarian Bahasa. Bandung: BBJB, hlm. 167. 
BPS Kalbar. 2010. Kalbar Dalam Angka. Pontianak: Artha Grafistama.

Badudu, J. S. 1985. Ilmu Bahasa Lapangan. Jakarta: Gramedia.

Effendi, Chairil. 2006. Becerite dan Bedande Tradisi Kesastraan Melayu Sambas. Pontianak: STAIN Press.

Effendi, Chairil. 2006. Sastra Sebagai Wadah Integrasi Budaya. Pontianak: STAIN Press.

Gaspersz, Steve G. TT. Masuk Melayu: Menegosiasikan Islam dan Kemelayuan di Malaysia. CivicCulture: Jurnal Ilmu Pendidikan PKn dan Sosial Budaya Vol. 3 No. 1, hlm. 3 .

Husny. 1986. Butir-butir Adat Budaya Melayu Pesisir Sumatra Timur. Jakarta: Depdikbud.

https://kbbi.kemdikbud.go.id/entri/ kempunan, diakses pada Agustus 2019.

Ibrahim, dkk. 2012. Pantang Larang Melayu Kalimantan Barat. Pontianak: STAIN Press.

Koentjaraningrat. 2015. Kebudayaan, Mentalitas, dan Pembangunan. Jakarta: Gramedia.

Mardimin, Johannes, dkk. 1994. Jangan Tangisi Tradisi, Transformasi Budaya Menuju Masyarakat Indonesia Modern. Yogyakarta: Kanisius.
Moleong, L.J. 2010. Metode Penelitian Kualitatif. Bandung: Remaja Rosdakarya.

Mustansyir, Rizal. 2017. Semiotika Kemponan Dalam Tradisi Masyarakat Melayu Sambas Kalbar: Dilemma Antara Agama dan Budaya. diunduh dari religidanbudaya.filsafat.ugm.ac.id/ 2017/10/26/semiotika-kemponandalam-tradisi-masyarakat-melayusambas-kalimantan-barat-dilemma-antara-budaya-agama/, diakses pada 23 Agustus 2019.

Huberman, A.M. dan Matthew B.M. 2014. Analisis Data Kualitatif. Jakarta: UI Press.

Pelly, Usman dan Asih Menanti. 1994. Teori-Teori Sosial Budaya. Jakarta: Depdikbud.

Saad, Muhammad Zubdi. 2003. Nasib Mendu dan Sejumlah Renungan Sufistik Anak Melayu. Pontianak: Mulyatama.

Shah, Abdul Hadi Harman dan Julaihi Wahid. 2010. Konsepsualisasi Ruang dan Habitat Tradisional Melayu. International Journal of the Malay World and Civilisation Vol. 28, No.1, hlm. 177-187.

Sunandar. 2015. Melayu Dalam Tantangan Globalisasi: Refleksi Sejarah dan Berubahnya Sistem Referensi Budaya. Jurnal Khatulistiwa Vol. 5, No.1, hlm. 2.

Wawancara. Maimun Binti Husin. Mempawah, 8 Januari 2015. 
Wawancara. Sataruddin Ramli.

Pontianak, 16 Januari 2015.

Wawancara. Syarifah Dayang. Batu

Ampar (Kubu Raya), 10 Februari

2015. 